\title{
A study on cervical cancer screening using pap smear in urban area in state of Meghalaya, India
}

\author{
Priti Mishra $^{1 *}$, Ragini Thapa², Arvind Kumar Dinkar ${ }^{3}$
}

\begin{abstract}
${ }^{1}$ Department of Obstetrics and Gynecology, ${ }^{2}$ Department of Pathology, Military Hospital Shillong, Meghalaya, India
${ }^{3}$ Department of Paediatrics, Institute of Child Health, Kolkata, West Bengal, India
\end{abstract}

\author{
Received: 22 April 2018 \\ Revised: 15 May 2018 \\ Accepted: 23 June 2018 \\ *Correspondence: \\ Dr. Priti Mishra, \\ E-mail: dr.mishrapriti@gmail.com
}

Copyright: () the author(s), publisher and licensee Medip Academy. This is an open-access article distributed under the terms of the Creative Commons Attribution Non-Commercial License, which permits unrestricted non-commercial use, distribution, and reproduction in any medium, provided the original work is properly cited.

\begin{abstract}
Background: Cancer cervix is fourth most common cancer in world second most common in India. The objective of the study is to identify abnormal pap smear cytology in women undergoing the test.

Methods: This retrospective study conducted in 200 women attending gynae OPD of Military Hospital, Shillong, Meghalaya, India between January 2016 to December 2017. Pap smear test was done, and classification was done as per Bethesda system 2014.

Results: 105 women had normal cytology findings and 23 had abnormal cytology.

Conclusions: Cervical cancer is the most common cancer for which screening is done. If pap smear is done every 3 years as per the guidelines mortality due to cervical cancer can be reduced. Every woman should undergo pap test at least once in her life before the age of 45 years. Timely screening of preinvasive lesion allows prevention from invasive cervical cancer.
\end{abstract}

Keywords: Cervical cancer, HSIL, LSIL, NILM, Pap smear

\section{INTRODUCTION}

Cervical cancer is fourth most common cancers in world. ${ }^{1}$ It is also among the commonest cause of deaths in developing countries like India. Developing countries account for $83 \%$ of cervical cancer and includes $15 \%$ female cancers. The situation in developing countries is different where it accounts for only $3.6 \%$ of new cases with a cumulative risk of only $0.8 \% .^{2-4}$

It second most common malignancy in India. ${ }^{5}$ There are $1,22,844$ cancer cervix cases in India every year. ${ }^{1}$ Timely diagnosis and treatment allows significant reduction by maternal mortality and morbidity. lifetime probability of cervical cancer is approximately 1 in 53 Indian women compared with 1 in 100 women in more developed regions of the world. ${ }^{6}$
In absence of a nationwide screening program there is always a disparity between cancer detection and treatment. As in rest of India cancer cervix is leading cancer in North Eastern states too.

In state of Meghalaya it is second most common cancer in female and accounts for $11.2 \%$ female cancers. ${ }^{7}$

Keeping in view the high incidence of the cervical cancer in the state of Meghalaya this study attempts to screen women attending Gynecology OPD of our institution and also impart awareness among them.

Aims and objective of this study were the study aimed to find incidence of abnormal pap smear cytology during screening, to evaluate awareness regarding screening program, to assess impact of screening program on 
women's health and to analyze result and plan follow up and treatment of patients.

\section{METHODS}

The study included 200 women attending gynae OPD of Military Hospital, Shillong, Meghalaya, India between January 2016-17.

\section{Inclusion criteria}

- Married women between 21 to 65 years

\section{Exclusion criteria}

- Women below 21 years.

- Women without sexual exposure.

- Women above 65 years.

\section{Procedure}

The method utilized was conventional pap smear cytology. Speculum examination of cervix was done.

Smear from ectocervix was taken using broad end of arye spatula rotating it 360 degrees. Sample from endocervix was taken using cytobrush and smear was made on a separate slide. After labelling slides were kept in $95 \%$ Ethanol fixative and sent to the laboratory. Evaluation was done using Bethesda system 2014. ${ }^{8}$

- Negative for intraepithelial lesion or malignancy

- Epithelial cell abnormalities

a) Squamous cell abnormalities

b) Atypical squamous cells (ASC)

c) ASC of undetermined significance (ASC-US)

d) ASC, cannot rule out high grade lesion (ASCUS)

e) Low-grade squamous intraepithelial lesion (LSIL)

f) High grade squamous intraepithelial lesion (HSIL)

g) Squamous cell carcinoma

h) Glandular cell abnormalities

i) Atypical glandular cells specify site of origin, if possible

j) Atypical glandular cells, favor neoplasia

k) Adenocarcinoma in situ Adenocarcinoma

- Non-Neoplastic findings
a) Cellular variations (atrophy, keratosis, metaplasia)
b) Reactive cellular changes (inflammation, repair, radiation)
c) Glandular cells status post hysterectomy
d) Organism: Trichomonas vaginalis, Fungal organisms consistent with Candida spp, Shift in flora suggestive of bacterial vaginosis, cellular changes consistent with herpes simplex virus, cellular changes consistent with

cytomegalovirus, Bacteria consistent with Actinomyces spp

e) Other Non-Neoplastic findings

- Endometrial cells in woman $\geq 45$ years of age

- Other malignant neoplasms (specified)

All the women with abnormal finding were followed up and underwent treatment as per standard protocol.

\section{RESULTS}

Most of the women who participated had undergone this test for the first time and were not aware of the test. Demographic distribution is summarized in Table 1.

Table 1: Sociodemographic distribution.

\begin{tabular}{|c|c|c|c|}
\hline & & $\begin{array}{l}\text { Number } \\
\text { (n) }\end{array}$ & Percentage \\
\hline \multirow{3}{*}{ Age group } & $21-30$ & 39 & 19.5 \\
\hline & $31-40$ & 116 & 58 \\
\hline & $41-65$ & 45 & 22.5 \\
\hline \multirow{3}{*}{ Parity } & Nullipara & 6 & 3 \\
\hline & Primipara & 27 & 13.5 \\
\hline & Multipara & 167 & 83.5 \\
\hline \multirow{2}{*}{ Marital status } & Yes & 200 & 100 \\
\hline & No & 0 & 0 \\
\hline \multirow{4}{*}{ Education } & Illiterate & 12 & 6 \\
\hline & $10^{\text {th }}$ Pass & 118 & 59 \\
\hline & $12^{\text {th }}$ Pass & 52 & 26 \\
\hline & $\begin{array}{l}\text { Graduate } \\
\text { and above }\end{array}$ & 18 & 9 \\
\hline \multirow{6}{*}{$\begin{array}{l}\text { Contraception } \\
\text { use }\end{array}$} & None & 63 & 31.5 \\
\hline & Barrier & 47 & 23.5 \\
\hline & $\begin{array}{l}\text { Coitus } \\
\text { interruptus }\end{array}$ & 24 & 12 \\
\hline & IUCD & 14 & 7 \\
\hline & $\begin{array}{l}\text { Tubal } \\
\text { ligation }\end{array}$ & 36 & 18 \\
\hline & Others & 8 & 4 \\
\hline \multirow[t]{2}{*}{$\begin{array}{l}\text { Smoking or } \\
\text { tobacco use }\end{array}$} & No & 188 & 94 \\
\hline & Yes & 12 & 6 \\
\hline
\end{tabular}

Mean age of women who underwent study was $36 \pm 7.5$ years. Out of 200 women $167(83.5 \%)$ were multiparous and only $6(3 \%)$ were nulliparous. All the women were married and gave history of monogamous relationship. Majority of women were educated only up to $10^{\text {th }}$ class $(59 \%)$ and only $18 \%$ were graduate and above. 63 $(31.5 \%)$ women did not use any family planning methods. Most of them did not give any history of addiction to smoking or tobacco in any form.

Prior to taking test women were asked about presence of any symptoms. $21 \%$ women were asymptomatic. Most common presenting complaint was discharge $\mathrm{p} / \mathrm{v}(52 \%)$. Intermenstrual bleeding post coital bleeding and pruritis 
vulvae were present respectively in $10 \%, 4 \%$ and $18 \%$ women. Table 2 summarizes the clinical presentations.

Table 2: Clinical presentations.

\begin{tabular}{|lll|}
\hline Presenting complaints & Number & Percentage \\
\hline Asymptomatic & 32 & 16 \\
\hline Discharge p/v & 104 & 52 \\
\hline Intermenstrual bleeding & 20 & 10 \\
\hline Post coital bleeding & 8 & 4 \\
\hline Pruritis vulvae & 36 & 18 \\
\hline
\end{tabular}

On speculum examination (Table 3) most common finding was healthy looking cervix $(53 \%)$ followed by discharge (48\%). 34.5\% women had cervical erosion, $27 \%$ had chronic cervicitis and $12 \%$ bled on touch.

Table 3: Speculum findings.

\begin{tabular}{|lll|}
\hline Speculum examination & Number & Percentage \\
\hline Healthy cervix & 106 & 53 \\
\hline Cervical erosion & 69 & 34.5 \\
\hline Chronic cervicitis & 54 & 27 \\
\hline Discharge & 96 & 48 \\
\hline Bleeding on touch & 24 & 12 \\
\hline
\end{tabular}

When cytological examination (Table 4) was done it was found that $52.5 \%$ were reported to be negative for intraepithelial lesion (NILM), 36\% had inflammatory smear,3.5\% had ASCUS, ASC-H was found only in $0.5 \%$, LSIL and HSIL were reported in 4 and $1 \%$ women respectively. There was no case of glandular cell abnormality.

Table 4: Pap smear cytology.

\begin{tabular}{|lll|}
\hline Pap smear cytology & Number & Percentage \\
\hline NILM & 105 & 52.5 \\
\hline Inflammatory & 72 & 36 \\
\hline Nonspecific findings & 5 & 2.5 \\
\hline ASCUS & 7 & 3.5 \\
\hline ASC-H & 1 & 0.5 \\
\hline LSIL & 8 & 4 \\
\hline HSIL & 2 & 1 \\
\hline SCC & 1 & 0.5 \\
\hline Glandular cell abnormality & 0 & 0 \\
\hline
\end{tabular}

Abnormal findings in pap smear were followed up as per ASCCP 2013 guidelines and coloposcopic examination followed by cervical biopsy was done if indicated. ${ }^{8}$ Out of 21 abnormal findings in pap smear cytology 15 required cervical biopsy.

CIN 1 was reported in 6 histopathological specimens and CIN2 and 3 in 3 and 2 cases repectively.one was diagnosed to be invasive squamous cell carcinoma. These histopathological abnormalities were managed further as per the guidelines.

\section{DISCUSSION}

Cervical cancer is the most common cancer for which screening is done. Cervical cancer is preceded by premalignant stage and it take $10-15$ years to progress. It is a well-known fact that cervical smear cytology can detect precancerous lesion of cervix at early stages and can reduce mortality and morbidity related to cervical cancer. Risk factors for cervical cancer are persistent or chronic infection with high risk HPV 16, 18, 31, 33, 45, 58; immunodeficiency; tobacco smoking; immunodeficiency; presence of other sexually transmitted diseases and long term oral contraceptive use. $^{9}$

Total fertiliy rate in India is 2.3 and India state of Meghalaya it is 2.7 and in the present study also the mean parity was $3 \pm 1.4$ which can be considered high parity. ${ }^{10}$ There is not much awareness of contraception in women of our study group. In the present study it was found that $31.5 \%$ women used no contraception and oral contraceptive usage was only 4\%. Although smoking along females is common in females in state of Meghalaya $(43.7 \%)$ but in the present study population only $6 \%$ women. ${ }^{11}$

If pap smear is done every 3 years as per the guidelines mortality due to cervical cancer can be reduced up to $80 \% .{ }^{12}$ In the present study most of the women got their pap test done for the first time. The mean age of the present study population was $36 \pm 7.5$. Most commonly cancer cervix occurs between 40-50 years and its preinvasive lesions occur 5-10 years prior. It is therefore recommended that every woman should undergo pap test at least once in her life before the age of 45 years. ${ }^{13,14}$

In present study there were 200 smears examined and $3.5 \%$ were reported to be ASC-US whereas only $0.5 \%$ consisted of ASC-H. LSIL and Hsil comprised of $1 \%$ and $0.5 \%$ respectively. Only $0.5 \%$ patients had squamous cell carcinoma. High percentage of inflammatory pattern with increased neutrophils in smears also indicate poor perineal hygiene.

Table 5: Comparison of abnormal pap smear cytology.

\begin{tabular}{|llll|}
\hline & $\begin{array}{l}\text { Present } \\
\text { study }\end{array}$ & $\begin{array}{l}\text { Sunita et } \\
\mathrm{al}^{15}\end{array}$ & $\begin{array}{l}\text { Nayir et } \\
\mathrm{al}^{16}\end{array}$ \\
\hline ASCUS & $3.5 \%$ & $2.3 \%$ & $1.7 \%$ \\
\hline ASC-H & 0.5 & - & $0.2 \%$ \\
\hline LSIL & $4 \%$ & $1.9 \%$ & $0.5 \%$ \\
\hline HSIL & $1 \%$ & $0.3 \%$ & $0.1 \%$ \\
\hline SCC & $0.5 \%$ & $0.5 \%$ & - \\
\hline Total & $9.5 \%$ & $5 \%$ & $2.5 \%$ \\
\hline
\end{tabular}

In the present study $95(45.5 \%)$ women were found to have abnormal pap smear cytology whereas in study conducted by Sunita et al $433(77.32 \%)$ reports were abnormal. ${ }^{15}$ Inflammatory smear reports were $72(36 \%)$ 
in our study, whereas it was high in studies conducted by Nayir et al $403 \quad(71.96 \%) .{ }^{16}$ Comparison between epithelial cell abnormality in our study and other studies is given in Table 5. The difference between cervical smear findings may be because of difference in socio demographic distribution, age and difference in awareness regarding screening programs. With the present study we conclude that among women in early marriages, high parity, illiteracy leading to poor personal hygiene which leads to infections oral contraceptive use are major risk factors for cervical cancer. In spite of these risk factors there was low prevalence of atypical epithelial cell abnormalities. Modifiable factors in risk factors should be further evaluated such as patterns in cultural characters, sexual behavior and contraceptive awareness

\section{CONCLUSION}

Screening of cancer cervix can detect preinvasive lesions like CIN and timely intervention can be done and prevent development of invasive cancer. But knowledge regarding cervical cancer and pap smear is very poor. It is therefore important that there should be awareness program and educational activities for cervical cancer. Patients attending outpatient department for routine problems should also be counselled for the same. By introducing a well-planned screening program, we can reduce cervical cancer related mortality and morbidity.

\section{Funding: No funding sources}

Conflict of interest: None declared

Ethical approval: The study was approved by the Institutional Ethics Committee

\section{REFERENCES}

1. Ferlay J, Soerjomataram I, Ervik M, Forman D, Bray F, Dixit R, et al. GLOBOCAN 2012, Cancer Incidence and Mortality Worldwide in 2012. Lyon, France: International Agency for Research on Cancer; 2012. [Last accessed on 2015 Dec 03]. Available at http://www.globocan.iarc.fr

2. Shanta V, Krishnamurthi S, Gajalakshmi CK, Swaminathan R, Ravichandran K. Epidemiology of cancer of cervix: global and national perspective. J Indian Med Assoc. 2000;98:49-52.

3. WHO. Cervix Cancer Screening. Volume 10. Lyon: IARC Press; 2001. IARC Handbooks on Cancer Prevention.

4. Parkin DM, Bray F, Ferlay J, Pisani P. Global cancer statistics, 2002. CA Cancer J Clin. 2005;55:7-108.

5. Musmar SG. Pattern and factors affecting Pap smear test in Nablus, a retrospective study. Middle East J Family Med. 2004;4:1-11.
6. Institute for Health Metrics and Evaluation. The Challenge Ahead: Progress in Breast and Cervical Cancer. Institute of Health Metrics and Evaluation. 2011. [Last accessed on 2016 Jan 21]. Available at http://www.healthmetricsandevaluation.org/publications /policyreport/challenge-ahead-progress-andsetbacksbreastand-cervical-cancer.

7. Incidence, Distribution, Trends in Incidence Rates and Projections of Burden of Cancer. Three-year report of population based cancer registries 2012-2014. Bengaluru: National Centre for Disease Informatics and Research, National Cancer Registry Program (ICMR); 2016. Available at http://ncdirindia.org/NCRP/ALL_NCRP_REPORTS/P BCR_REPORT_2012_2014/ALL_CONTENT/Printed_ Version.htm, accessed on February 1, 2018

8. Nayar R, Wilbur DC. The Bethesda System for reporting cervical cytology: definitions, criteria, and explanatory notes. $3^{\text {rd }}$ ed. New York, Springer; 2015.

9. Bruni L, Barrionuevo-Rosas L, Albero G, Serrano B, Mena M, Gómez D, et al. ICO/IARC Information Centre on HPV and Cancer (HPV Information Centre). Human Papillomavirus and Related Diseases in India. Summary Report 27 July 2017

10. Sampl Registration System 2011.Trend of Birth rate, Death rate, Infant Mortality rate, Total Fertility rate, Sex ratio at Birth and Sex ratio of children (0-4 age group), India. Available at http://www.censusindia.gov.in/vital_statistics/SRS_Rep ort Accessed on 4 July 2018

11. Sinha DN, Gupta PC, Pednekar MS. Tobacco use among students in the eight North-eastern states of India. Indian J Cancer. 2003;40:43-59.

12. Nayir T, Okyay AR, Nizlican E, Yesilyurt H, Akbaba $\mathrm{M}$, Ilhan B, et al. Cervical cancer screening in an early diagnosis and screening centre in Mersin, Turkey. Asian Pac J Cancer Prev. 2015;16:6909-12.

13. Shanmugham D, Vijay A, Rangaswamy T. Colposcopic evaluation of patient with persistant inflammatory pap smear. Sch J App Med Sci. 2014;2:1010-3.

14. Maleki A, Ahmadina E, Avazeh A, Mazloomzadeh S, Molaei B, Jalilvand A. Prevelance of abnormal papanicolaou test results and related factors among women living in Zanjan, Iran. Asian Pac J Cancer Prev. 2015;16:6935-9.

15. Bamanikar SA, Baravkar DS, Chandanwale SS, Dapkekar P. Study of cervical pap smears in a tertiary hospital. Indian Medical Gazette. 2014:250-4.

16. Nayir T, Okyay AR, Nizlican E, Yesilyurt H, Akbaba $\mathrm{M}$, Ilhan B, et al. Cervical cancer screening in an early diagnosis and screening centre in Mersin, Turkey. Asian Pac J Cancer Prev. 2015;16:6909-12.

Cite this article as: Mishra P, Thapa R, Dinkar AK. A study on cervical cancer screening using pap smear in urban area in state of Meghalaya, India. Int $\mathbf{J}$ Reprod Contracept Obstet Gynecol 2018;7:3113-6. 